\title{
Effect of Glass Fiber Post Diameter on Fracture Resistance of Endodontically Treated Teeth
}

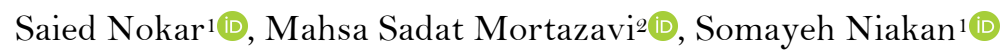

${ }^{1}$ Department of Prosthodontics, Dental Research Center, Tehran University of Medical Sciences, Tehran, Iran.

${ }^{2}$ Department of Orthodontics, Arthur A. Dugoni School of Dentistry, University of the Pacific, San Francisco, USA.

Author to whom correspondence should be addressed: Somayeh Niakan, Department of Prosthodontics, Dental Research Center, Tehran University of Medical Sciences, North Karegar St, Tehran, Iran. 14399-55991. Phone: +989126727694. Email: drsomayehniakan@yahoo.com.

Academic Editors: Alessandro Leite Cavalcanti and Wilton Wilney Nascimento Padilha

Received: 01 December 2019 / Accepted: 28 February 2020 / Published: 09 March 2020

How to cite this article: Nokar S, Mortazavi MS, Niakan S. Effect of glass fiber post diameter on fracture resistance of
endodontically treated teeth. Pesqui Bras Odontopediatria Clín Integr. 2020; 20 :e5413.
https://doi.org/10.1590/pboci.2020.044

\begin{abstract}
Objective: To determine the fracture resistance of endodontically treated teeth restored with three different diameters of glass fiber posts and metal-ceramic crowns. Material and Methods: Thirty human maxillary canines were selected and subjected to root canal therapy. The teeth were randomly divided into three groups of glass fiber posts with $1.4 \mathrm{~mm}$ diameter (Group I), $1.6 \mathrm{~mm}$ diameter (Group II), and $2.0 \mathrm{~mm}$ diameter (Group III). The teeth were restored with metal-ceramic crowns and subjected to the compressive load applied at $45^{\circ}$ angle to the longitudinal axis until fracture. The mode of failure was determined. Data were analyzed using ANOVA, followed by Tukey's post hoc multiple comparisons test $(\mathrm{p}<0.05)$. Results: The mean fracture resistance of groups I, II and III was $574 \pm 91.2 \mathrm{~N}, 617 \pm 85.21 \mathrm{~N}$ and $467 \pm 99.43 \mathrm{~N}$, respectively. No significant difference was noted between groups I and II, while the fracture resistance was significantly different between groups I and III $(\mathrm{p}<0.05)$ and groups II and III $(\mathrm{p}<0.05)$. No case of post fracture alone occurred in any group. Conclusion: The diameter of glass fiber posts can affect the fracture resistance of teeth. Based on the results, increasing the diameter of the post up to $1.6 \mathrm{~mm}$ may increase the fracture resistance of root, although excessive diameters are not recommended.
\end{abstract}

Keywords: Post and Core Technique; Tooth, Nonvital; Flexural Strength. 


\section{Introduction}

The concept of post and core restoration has changed in recent years. Different intracanal posts are available, each having advantages and disadvantages [1,2]. Pre-fabricated posts are especially popular as they can be placed within one session and they are easy to use and affordable [3]. Use of bonding agents and resin cements along with non-metallic posts such as carbon fiber, quartz fiber and glass fiber posts results in suitable stress distribution and consequently increases the fracture resistance of teeth [4-6].

Fiber-reinforced composite posts have advantages such as a modulus of elasticity similar to that of dentin [7]. Likewise, post diameter is an important factor affecting the biomechanical behavior of the treated teeth $[4,8]$. However, some contradictory results have been reported regarding the effect of post diameter on fracture resistance of roots [9]. Posts with larger diameters increase the risk of root fracture [4]. On the other hand, most materials used for post-fabrication need to have a certain diameter to exert optimal physical properties and resist fracture under functional and parafunctional loads [4,9].

The three theories for the use of metallic posts include placing the smallest post diameter possible, post diameter being equal or smaller than one-third of the root diameter and ensuring the presence of $1 \mathrm{~mm}$ dentin around the post [10]. However, it is not clear whether these theories apply to glass fiber posts or not. Looking for interest in dental research [11-15], the objective of the present study was to assess the effect of the diameter of glass fiber posts on fracture resistance of endodontically treated teeth restored with crowns. The null hypothesis was that the diameter of glass fiber posts does not influence the fracture resistance of endodontically treated teeth with crowns.

\section{Material and Methods}

Study Design and Sample

In this in vitro, experimental study, 30 freshly extracted single-rooted human canine teeth were selected and inspected to ensure the absence of cracks, caries, root attrition, erosion and previous endodontic treatment $[16,17]$. The shape and diameter of the teeth were almost similar.

\section{Root Canal Preparation}

The teeth were stored in chloramine $\mathrm{T}$ solution (Merck Schanchardt, Hohenbraun, Germany) for 2 days for disinfection [18]. Soft tissue residues and debris were removed with hand and ultrasonic scalers and the teeth were stored in saline at $4{ }^{\circ} \mathrm{C}$ for a maximum of three months [19]. The buccolingual and mesiodistal dimensions of the teeth were measured at three points of $5 \mathrm{~mm}, 10 \mathrm{~mm}$ and $15 \mathrm{~mm}$ from the root apex using a digital caliper (Vernier Caliper, Tricle Brand, Shanghais, China) with $0.01 \mathrm{~mm}$ accuracy. The teeth were randomly assigned into three groups. At $5 \mathrm{~mm}$ distance from the root apex, the mean root diameter was 4.45 $\mathrm{mm}$ at the buccolingual and $3.79 \mathrm{~mm}$ at the mesiodistal dimension while these values were $6.53 \mathrm{~mm}$ and 4.61 $\mathrm{mm}$ at $10 \mathrm{~mm}$ and $7.73 \mathrm{~mm}$ and $6.01 \mathrm{~mm}$ at $15 \mathrm{~mm}$ from the root apex, respectively.

The teeth were endodontically treated with hand instruments. After access cavity preparation, the canal path was opened using a \#15 stainless steel K-file (Mani Inc., Kiyohara Tochigi, Japan). The cleaning and shaping of the canal were performed using the step-back technique to $1 \mathrm{~mm}$ from the root apex. A \#40 master apical file was used and all canals were instrumented up to \#70 K-file [20-22]. The canals were irrigated with $5.25 \%$ sodium hypochlorite, and the length was radiographically controlled. The canals were dried with paper points, filled with eugenol-free sealer (AH26; Dentsply, DeTrey, Konstanz, Germany), and filled with guttapercha points (Gapadent Co. LTD, Tian Jin City, China) using the lateral compaction technique [22]. 
The coronal portions of the teeth were cut at $17 \mathrm{~mm}$ distance from the root apex using a disc and lowspeed hand-piece, leaving $2 \mathrm{~mm}$ for the ferrule effect, $10 \mathrm{~mm}$ for the post length and a final $5 \mathrm{~mm}$ for guttapercha (Figure 1A). All canal orifices were examined to be smaller than their respective posts.

In the first group, the post space was prepared with a special post bur with $1.44 \mathrm{~mm}$ diameter (Glass Fiber Conical, Angelus, Brazil) and up to $12 \mathrm{~mm}$ length. ED Primer II (Kuraray Medical Inc., Okayama, Japan) was applied into the post space and the coronal dentin was dried with paper point and gentle air-flow for 60 seconds according to the manufacturer's instructions. Panavia F 2.0 dual-core resin cement (Kuraray Medical Inc., Okayama, Japan) was mixed for 20 seconds and directly applied on the post surface. The Exacto $\mathrm{N}^{\circ} 1$ posts were inserted into the canals with finger pressure and light-cured for 40 seconds from the buccal and lingual directions. The polymerization process was completed by applying Oxyguard II on resin cement surfaces.

The cores with $8 \mathrm{~mm}$ height were fabricated using Clearfil Photo Core (Kuraray Medical Inc., Okayama, Japan) composite resin using non-anatomical celluloid molds to maintain similar core dimensions (TENA, Aulnay-Sous-Bois, France) (Figure 1B). When the composite was applied into the molds, the complex was light-cured for 40 seconds at both buccal and lingual directions. Subsequently, the teeth were prepared by an expert clinician using a flat-end taper bur and high-speed handpiece under water spray (Figure $1 \mathrm{C}$ ). In the second group, the same procedures were repeated using a post (Exacto $\mathrm{N}^{\circ} 2$ ) with $1.6 \mathrm{~mm}$ diameter, and a special bur for post space preparation. In the third group, Exacto $\mathrm{N}^{\circ} 3$ post with $2 \mathrm{~mm}$ diameter was used.

The roots of each tooth were embedded in auto-polymerizing acrylic resin (Meliodent, \#64713278 Heraeus Kulzer, Hanau, Germany), which was extended from the bottom to $3 \mathrm{~mm}$ below the preparation margin. The acrylic resin was added around the teeth in multiple stages to overcome polymerization shrinkage and prevent overheating. Impressions were made by polyvinyl siloxane impression material (Zhermack GmbH Deutschland, Marl, Germany) and were poured with gypsum. The metal-ceramic crowns were then fabricated. The crown length was determined to be $10 \mathrm{~mm}$ and they were cemented on the respective teeth using Panavia F2.0 resin cement. For testing of fracture resistance in a universal testing machine (Zwick Roell Group, Ulm, Germany), the teeth were placed in a holder (Figure 1D). The load was applied at $45^{\circ}$ angle relative to the horizontal axis at a crosshead speed of $1 \mathrm{~mm} / \mathrm{minute}$ [23]. The load at failure was recorded.
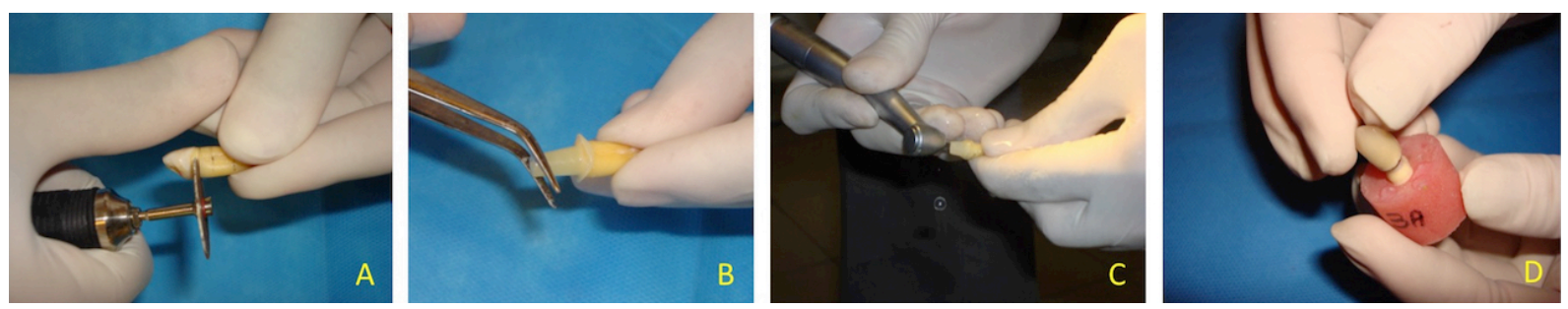

Figure 1. A) Coronal removal at the $17 \mathrm{~mm}$ distance from the root end. B) Core fabrication. C) Core preparation. D) Crown cementation.

\section{Data Analysis}

The fracture resistance data of the three groups were analyzed using ANOVA $(p<0.05)$ followed by Tukey's post hoc multiple comparisons test. To ensure the accuracy, the mode of failure of the specimens was evaluated under a stereomicroscope (Nikon Inc., Tokyo, Japan) after the fracture (at the core, root or post surfaces).

\section{Ethical Aspects}


This research project was approved by the Faculty of Dentistry, Tehran University of Medical Sciences Research center, project number 4752 .

\section{Results}

The mean fracture resistance was $467 \pm 99.42 \mathrm{~N}$ for Exacto $\mathrm{N}^{\circ} 3$ posts with $2 \mathrm{~mm}$ diameter, $617 \pm$ $85.21 \mathrm{~N}$ for Exacto $\mathrm{N}^{\circ} 2$ posts with $1.6 \mathrm{~mm}$ diameter and $574 \pm 91.2 \mathrm{~N}$ for Exacto $\mathrm{N}^{\circ} 1$ posts with $1.4 \mathrm{~mm}$ diameter (Figure 2). ANOVA revealed a significant difference in the mean fracture resistance of the groups $(\mathrm{p}<0.05)$. According to Tukey's post hoc test, the fracture resistance of Exacto $\mathrm{N}^{\circ} 1$ posts was not significantly different from the mean value obtained for Exacto $\mathrm{N}^{\circ} 2$ posts $(\mathrm{p}>0.05)$ while significant differences were found between Exacto $\mathrm{N}^{\circ} 3$ and Exacto $\mathrm{N}^{\circ} 1$ posts $(\mathrm{p}<0.05)$ as well as Exacto $\mathrm{N}^{\circ} 2$ and Exacto $\mathrm{N}^{\circ} 3$ posts.

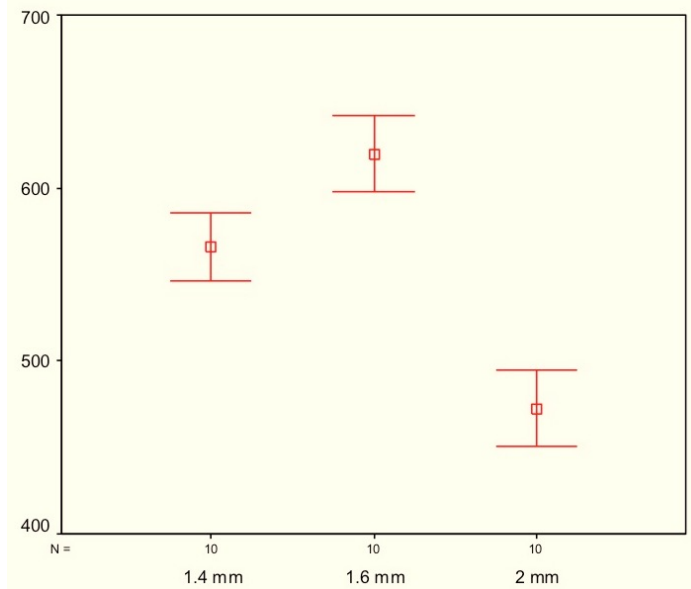

Figure 2. 95\% confidence interval of the mean fracture resistance values for the three groups.

Regarding the mode of failure, in Exacto $\mathrm{N}^{\circ} 1$ and Exacto $\mathrm{N}^{\circ} 2$ groups, nine teeth $(90 \%)$ showed core fracture and one $(10 \%)$ tooth demonstrated fracture in the root. However, in Exacto $\mathrm{N}^{\circ} 3$ group, four teeth $(40 \%)$ showed root fracture and six teeth $(60 \%)$ showed core fracture. In all teeth, the post fractures were observed in the core or the root (Table 1 and Figure 3 ).

Table 1. Fracture pattern in the root canals with posts of different diameters.

\begin{tabular}{cccc}
\hline Groups & Post & Core & Root \\
& $\mathrm{N}(\%)$ & $\mathrm{N}(\%)$ & $\mathrm{N}(\%)$ \\
\hline Exacto $\mathrm{N}^{\circ} 1$ & $1(10.0)$ & $9(90.0)$ & $10(100.0)$ \\
Exacto $\mathrm{N}^{\circ} 2$ & $1(10.0)$ & $9(90.0)$ & $10(100.0)$ \\
Exacto $\mathrm{N}^{\circ} 3$ & $4(40.0)$ & $6(60.0)$ & $10(100.0)$ \\
\hline
\end{tabular}
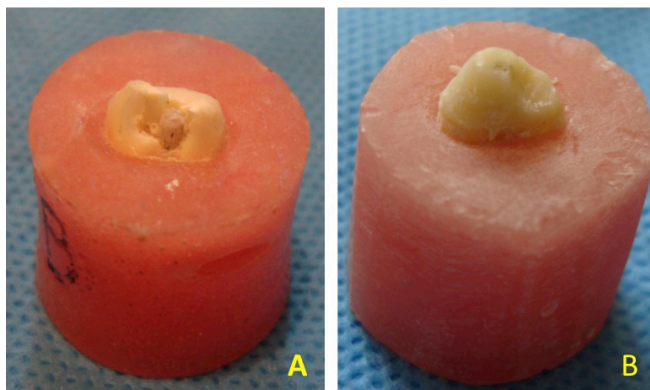

Figure 3. A) Core and post fracture. B) Root and post fracture. 


\section{Discussion}

This study compared the fracture resistance of endodontically treated teeth restored with posts with three different diameters. The results showed significant differences between group III with groups I and II. Also, a slight insignificant increase was noted with an increase in post diameter from $1.4 \mathrm{~mm}$ to $1.6 \mathrm{~mm}$. Therefore, the increase in glass fiber post diameter up to 1.6 was associated with an increase in fracture resistance.

It seems that glass fiber posts distribute the loads more uniformly on the root surface due to having an elasticity coefficient similar to that of dentin well as forming a homogenous structure with the composite core and resin cement [1,4]. However, the remaining dental substrate is a major factor affecting the fracture resistance of endodontically treated teeth [24]. But, some authors have stated that nonmetallic posts create a pressure zone similar to that of natural teeth, and the maximum concentration of pressure has no significant association with post diameter. Moreover, as increased diameter does not weaken the root due to the use of bonding systems, nonmetallic posts with larger diameters are recommended [19,25-27].

Furthermore, some authors recommended using large glass fiber posts to achieve a more stabilized core when restoring teeth with extensive coronal defects and showed that despite the reduced thickness of dentin when inserting larger-diameter posts, fracture resistance had no correlation with the diameter of the fiber post [28]. It was also found that different diameters of glass fiber posts did not affect the distribution of stress around the restored teeth [29].

A previous study analyzed different diameters (1.2, 1.4 and $1.6 \mathrm{~mm}$ ) of glass fiber posts with a composite core in maxillary central incisors and showed that stress concentration in roots and composite resin cores decreased by use of fiber posts with larger diameters. The authors suggested using composite cores with larger diameters of glass fiber posts in teeth with extensive coronal defects to decrease stress distribution in the remaining root structure [30]. The present study showed higher fracture resistance with a slight increase in post diameter from 1.4 to $1.6 \mathrm{~mm}$, similar to the aforementioned studies.

Some researchers compared the effect of different diameters (\#0.5, \#2, \#3) of quartz fiber posts on fracture resistance of roots and suggested that by increasing the diameter of the post, reduction in wall thickness of root canal would be compensated by the increase in the bonding surface area, and formation of an integrated complex of post and root in crownless teeth [31]. However, in the present study, after increasing the diameter of the post by $2 \mathrm{~mm}$, significant reductions were noted in fracture resistance of restorations. This contrast may arise from the use of different post materials and methodologies. In contrast to our study, previous authors evaluated crownless teeth [31]. Furthermore, the differences observed in fracture resistance of the posts with different diameters or systems can be justified by different elastic moduli of the posts. Using a post with an elastic modulus closer to that of dentin and the core may prevent stress concentration at the postcore-cement interfaces [26,32].

It has been shown that luting-bonding agents can significantly improve the retention of posts inserted into resin core materials [33,34]. Voids at the interface of post and core may result from inadequate condensation of the core material around the post and may negatively affect the integration of post and core and decrease the fracture resistance of the post and core against compressive loads. Thus, resin-luting agents can be applied on the posts before core shaping to improve bonding of the post tip and core [34]. In the present study, all specimens were prepared in this manner.

Masticatory loads are also important in fracture resistance of restored endodontically treated teeth; these loads decrease from the molar area to the incisors region with the mean value of $215 \mathrm{~N}$ in a maxillary 
canine, which can be increased to $254.8 \mathrm{~N}$ in the presence of parafunctional habits $[6,35]$. It is clear that the mean fracture resistance of all specimens in the present study was significantly higher than the maximum physiologic loads tolerated by teeth in the oral environment. However, fatigue pressure due to constant application of lower forces can cause tooth or restoration fracture.

In the present study, no case of post fracture alone occurred, as shown by previous authors [36]. This finding may be attributed to the use of resin cement, which causes the complex of tooth-core-post to function as an integrated unit. Thus, the fracture resistance of the post increases and the applied forces are well tolerated [36]. On the other hand, only one root fracture was observed in groups I and II, while 4 root fractures occurred in group III, which is probably attributed to root weakening because of using a large post diameter.

The results of in vitro experimental studies must be interpreted with caution as different factors such as the tooth properties prior to extraction, age, pulp status during tooth extraction, root anatomy and dimensions, the load angle and tooth position have significant effects on fracture resistance [24]. Furthermore, in vitro methodologies cannot precisely simulate the oral environment [6].

\section{Conclusion}

Within the limitations of this study, increasing the post diameter affects the fracture strength. However, the three groups were within the clinically acceptable range in terms of fracture strength.

\section{Authors' Contributions}

SN $\quad$ (D) 0000-0003-2278-4697 $\begin{aligned} & \text { Conceptualization, Methodology, Software, Validation, Formal Analysis, Project } \\ & \text { Administration and Funding Acquisition. }\end{aligned}$
$\begin{array}{lll}\text { MSM } & \text { (D) 0000-0003-3755-3250 } & \begin{array}{l}\text { Investigation and Resources. } \\ \text { SN }\end{array} \\ \text { Dll authors declare that they contributed to critical review of intellectual content and approval of the final version to be } \\ \text { Editing, Visualization and Supervision. }\end{array}$
published.

\section{Financial Support}

This study was supported by Deputy of Research Affairs, Faculty of Dentistry, Tehran University of Medical Sciences.

\section{Conflict of Interest}

The authors declare no conflicts of interest.

\section{Acknowledgements}

The present study was part of a Dissertation submitted to the Restorative Dentistry Department. Also, special thanks are given to Dr. M. J. Kharazi-Fard for his supervision of statistical analyses.

\section{References}

[1] Sadeghi M. A comparison of the fracture resistance of endodontically treated teeth using three different post systems. J Dent Tehran Univ Med Sci 2006; 3(2):69-76.

[Q] Sharafeddin F, Alavi AA, Zare S. Fracture resistance of structurally compromised premolar roots restored with single and accessory glass or quartz fiber posts. Dent Res J 2014; 11(2):264-71.

[3] Fernandes AS, Shetty S, Coutinho I. Factors determining post selection: a literature review. J Prosthet Dent 2003; 90(6):556-62. https://doi.org/10.1016/j.prosdent.2003.09.006 
[4] Nandini VV, Venkatesh V. Current concepts in the restoration of endodontically treated teeth. J Indian Prosthod Soc 2006; 6(2):63-7. https://doi.org/10.4103/0972-4052.27776

[5] Sahafi A, Peutzfeldt A, Asmussen E, Gotfredsen K. Retention and failure morphology of prefabricated posts. Int J Prosthodont 2004; 17(3):307-12.

[6] Turker SB, Alkumru HN, Akalin B. Fracture resistance of endodontically treated canines restored with different sizes of fiber post and all-ceramic crowns. J Adv Prosthodont 2016; 8(2):158-66. https://doi.org/10.4047/jap.2016.8.2.158

[7] Dastjerdi MR, Chaijan KA, Tavanafar S. Fracture resistance of upper central incisors restored with different posts and cores. Restor Dent Endod 2015; 40(3):229-35. https://doi.org/10.5395/rde.2015.40.3.229

[8] Kaur J, Verma PR, Sharma N, Kinra M. Review of stresses around post restorations - an insight view through finite element analysis. IOSR J Dent Med Sci 2015; 14(2):75-9.

[9] Assif D, Gorfil C. Biomechanical considerations in restoring endodontically treated teeth. J Prosthet Dent 1994; 71(6):565-7. https://doi.org/10.1016/0022-3913(94)90438-3

[10] Lloyd PM, Palik JF. The philosophies of dowel diameter preparation: a literature review. J Prosthet Dent 1993; 69(1):32-6. https://doi.org/10.1016/0022-3913(93)90236-h

[11] Ranjbar M, Noudeh GD, Hashemipour MA, Mohamadzadeh I. A systematic study and effect of PLA/Al2O3 nanoscaffolds as dental resins: mechanochemical properties. Artif Cells Nanomed Biotechnol 2019; 47(1):201-9. https://doi.org/10.1080/21691401.2018.1548472

[12] Ranjbar M, Pardakhty A, Tahmipour B, Mohamadzadeh I. Novel CaO/polylactic acid nanoscaffold as dental resin nanocomposites and the investigation of physicochemical properties. Luminescence 2019; 34(3):360-7. https://doi.org/10.1002/bio.3617

[13] Eskandarizadeh A, Parizi MT, Goroohi H, Badrian H, Asadi A, Khalighinejad N. Histological assessment of pulpal responses to resin modified glass ionomer cements in human teeth. Dent Res J 2015; 12(2):144-9.

[14] Rekabi AR, Ashouri R, Torabi M, Parirokh M, Abbott PV. Florid cemento-osseous dysplasia mimicking apical periodontitis: a case report. Aust Endod J 2013; 39(3):176-9. https://doi.org/10.1111/j.1747-4477.2011.00325.x

[15] Hashemipour MA, Ghasemi AR, Dogaheh MA, Torabi M. Effects of locally and systemically applied n-3 fatty acid on oral ulcer recovery process in rats. Wounds 2012; 24(9):258-66.

[16] Gu XH, Huang JP, Wang XX. An experimental study on fracture resistance of metal-ceramic crowned incisors with different post-core systems. Zhonghua Kou Qiang Yi Xue Za Zhi 2007; 42(3):169-72.

[17] Maccari PC, Cosme DC, Oshima HM, Burnett LH, Shinkai RS. Fracture strength of endodontically treated teeth with flared root canals and restored with different post systems. J Esthet Restor Dent 2007; 19(1):30-6.

[18] Rolland SL, Carrick TE, Walls AW, McCabe JF. Dentin decontamination using chloramine T prior to experiments involving bacteria. Dent Mater 23(12):1468-72.

[19] Monzavi A, Nokar S, Javadi HR. The effects of post diameter on stress distribution in maxillary central incisor, a three dimensional finite element study. J Dent Tehran Univ Med Sci 2004; 1(2):17-23.

[20] Adanir N, Belli S. Evaluation of different post lengths' effect on fracture resistance of a glass fiber post system. Eur J Dent 2008; 2:23-8.

[21] Al-Wahadni AM, Hamdan S, Al-Omiri M, Hammad MM, Hatamleh MM. Fracture resistance of teeth restored with different post systems: in vitro study. Oral Surg Oral Med Oral Pathol Oral Radiol Endod 2008; 106(2):e77-83. https://doi.org/10.1016/j.tripleo.2008.03.038

[22] Torabinejad M, Walton RE. Endodontics: Principles and Practice. London: Elsevier Health Sciences; 2009. 474pp.

[23] Abduljabbar T, Sherfudhin H, AlSaleh SA, Al-Helal AA, Al-Orini SS, Al-Aql NA. Fracture resistance of three post and core systems in endodontically treated teeth restored with all-ceramic crowns. King Saud Univ J Dent Sci 2012; 3(1):33-8. https://doi.org/10.1016/j.ksujds.2011.10.001

[24] Maccari PC, Conceicao EN, Nunes MF. Fracture resistance of endodontically treated teeth restored with three different prefabricated esthetic posts. J Esthet Restor Dent 2003; 15(1):25-30.

[25] Lassila LV, Tanner J, Le Bell AM, Narva K, Vallittu PK. Flexural properties of fiber reinforced root canal posts. Dent Mater 2004; 20(1):29-36. https://doi.org/10.1016/s0109-5641(03)00065-4

[26] Rodríguez-Cervantes PJ, Sancho-Bru JL, Barjau-Escribano A, Forner-Navarro L, Pérez-González A, Sánchez-Marín FT. Influence of prefabricated post dimensions on restored maxillary central incisors. J Oral Rehabil 2007; 34(2):14152. https://doi.org/10.1111/j.1365-2842.2006.01720.x

[27] Galhano GÁ, Valandro LF, De Melo RM, Scotti R, Bottino MA. Evaluation of the flexural strength of carbon fiber-, quartz fiber-, and glass fiber-based posts. J Endod 2005; 31(3):209-11. https://doi.org/10.1097/01.don.0000137652.49748.0c

[28] Baldissara P, Zicari F, Ciocca L, Zamboni SC, Valandro LF. Effect of fiber post emerging diameter on composite core stabilization. J Dent Res 2007; 86(Spec. Iss. A):2623.

[29] Boschian Pest L, Guidotti S, Pietrabissa R, Gagliani M. Stress distribution in a post-restored tooth using the threedimensional finite element method. J Oral Rehabil 2006; 33(9):690-7.

https://doi.org/1010.1111/j.1365-2842.2006.01538.x 
[30] Okamoto K, Ino T, Iwase N, Shimizu E, Suzuki M, Satoh G, et al. Three-dimensional finite element analysis of stress distribution in composite resin cores with fiber posts of varying diameters. Dent Mater J 2008; 27(1):49-55. https://doi.org/10.4012/dmj.27.49

[31] Jalalian E, Mirzaei M. In vitro evaluation of the effect of different diameters of quartz fiber posts on fracture resistance of dental roots. Rev Clín Pesq Odontol 2009; 5(1):29-36.

[32] Barjau-Escribano A, Sancho-Bru JL, Forner-Navarro L, Rodríguez-Cervantes PJ, Perez-Gonzalez A, Sanchez-Marin FT. Influence of prefabricated post material on restored teeth: fracture strength and stress distribution. Oper Dent 2006; 31(1):47-54. https://doi.org/10.2341/04-169

[33] Dilmener FT, Sipahi C, Dalkiz M. Resistance of three new esthetic post-and-core systems to compressive loading. J Prosthet Dent 2006; 95(2):130-6. https://doi.org/10.1016/j.prosdent.2005.11.013

[34] Aksoy G, Cotert HS, Korkut L. Effect of an adhesive resin luting agent on the dowel-head retention of three different core materials. J Prosthet Dent 2005; 93(5):439-45. https://doi.org/10.1016/j.prosdent.2005.02.025

[35] Lyons MF, Baxendale RH. A preliminary electromyographic study of bite force and jaw-closing muscle fatigue in human subjects with advanced tooth wear. J Oral Rehabil 1990; 17(4):311-8. https://doi.org/10.1111/j.1365-2842.1990.tboo014.x

[36] Ng CC, Al-Bayat MI, Dumbrigue HB, Griggs JA, Wakefield CW. Effect of no ferrule on failure of teeth restored with bonded posts and cores. Gen Dent 2004; 52(2):143-6. 